\title{
Global South and the Narratives of Dissent: A Cross-Cultural Perspective
}

Dr. Syed Wahaj Mohsin

Associate Professor

Department of English/Languages

Integral University

Lucknow, India

swahaj@iul.ac.in

Shaista Wahaj

Master of Philosophy

(M.Phil.) in English,

Vinayaka Mission University,

Salem, Tamil Nadu, in 2009, India

Abstract

It will not be incorrect to refer to "Global South" as a blanket term rather than an umbrella term that has both an enormous and complex structure. Innumerable nations of this world have been tagged as the nations belonging to the Global South. This demarcation between the Global South and the Global North is an ever-deepening abyss that has serious consequences in terms of global citizenship and harmony. The binary opposition between the Global North and the Global South cannot be blurred unless the privileged populations of the economically 
sound nations begin to realize that a majority of the people living in the Global South are competent, modern, rational, urban and civilized. A clichéd image of the South as wild, uncivilized and inferior must be abandoned to obtain an authentic outlook.

The growing disparity between the Global North and the Global South has fuelled literary production. The narratives emerging from the Global South are both immensely vibrant and diverse. A vast constellation of thematic concerns have been acknowledged and brought to the surface. The literary discourse that is being propelled by the Global South is thoughtprovoking, richly textured and rooted in the lived reality of the people of the South. The Southern writers feel that the impunity of the North can only be confronted by means of eloquent discourse.

This scholarly paper aims to sketch a glimpse of the contemporary writers of the Global South who have been vehemently writing works of fiction, non-fiction, poetry and creative nonfiction with the aim of creating global awareness. Some such authors include Tehmina Durrani and Faiqa Mansab from Pakistan, Nawal El Saadawi from Egypt, Tahmima Anam, Monica Ali and Zia Haider Rahman from Bangladesh, Arundhati Roy from India, Mario Vargas Llosa, Giannina Braschi and Junot Díaz from Latin America and Nnedi Okorafor, Tanure Ojaide and Ben Okri from Nigeria. The future of research in this sphere is bound to be vast and complex.

Keywords: Global South, Discourse, Dissent, Cross-Cultural perspective 
Words should not seek to please, should not hide the wounds in our bodies, the shameful moments in our lives. Sometimes words shock us, give us pain, but they can provoke us to face ourselves, to question what we have accepted for thousands of years.

- Nawal El-Saadawi

The binary opposition between Global North and Global South has been tremendously amplified during the contemporary scenario. Irrespective of this term's geographical connotation, it is being blatantly used to assign superiority to some nations of the world upon other nations on economic, social and political grounds. The developing nations and the economically weak nations are clustered together as Global South without taking into account their consent to this biased categorization. Most of the nations tagged as Global South are previous colonies of the Europeans. In order to establish some sort of domination and hegemony the colonizers of the past have clubbed all their previously owned colonies in the Global South without making this act obvious. They have 'othered' these nations under the banner of Global South so as to ascertain their authority and bask in the glory of their false sense of superiority. Global South is the 'other,' the 'subaltern' that is made up of the nations that still need to civilize according to the nations of the Global North. The nations are being forced to believe that they are lacking in something that the Global North possesses. Creation of Global North and Global South are not strictly geographical, and hence it is a concept based on equality and injustice. It is camouflaged as a geographical phenomenon, but in reality it is sheer arrogance of the superpowers and a measure to centralize power in their hands.

The othering of the Global South by the Global North (hereafter referred to as GN and GS), has opened many avenues of literary discourse for the writers of the GS because the writers have become more and more politically, socially and culturally aware of the 
predicaments of being the 'other'. The disparity between the GS and the GN has fuelled the production of literature on a grand scale. International accolades are being grabbed by the writers of the GS so as to establish and assert their position and repute in the literary coterie across the globe. By no means do these writers allow their writings to be short of narrative dexterity. Their versatile narratives and cross-cultural perspectives add to the already rich storehouse of literature. Nobel Prize for literature has often been awarded to writers from the GS. Some such acclaimed writers include Rabindra Nath Tagore (1913) from India, Naguib Mahfouz (1988) from Egypt, Nadine Gordimer (1991) from South Africa, José Saramago (1998) from Portugal, J.M. Coetzee (2003) from South Africa, Orhan Pamuk (2006) from Istanbul and Svetlana Alexievich (2015) from Ukraine. Similarly, the prestigious Man Booker Prize has been awarded to many authors from the GS including, Nadine Gordimer (1974) from South Africa, Arundhati Roy (1997) from India, Kiran Desai in 2006 was also from India and Marlon James (2015) from Jamaica.

By means of massive literary reproduction the writers of the GS have achieved an international repute and are being unanimously appreciated by literary theorists and critics for bringing to the forefront the peripheral issues and concerns. It is by means of literature that the people of the GN can be sensitized about the problems and issues of the people of the GS. A true and factual presentation of GS can be an eye-opener for the nations who take pride and boast of their superiority on account of their economic strength. The previously colonized nations cannot become superpowers instantly. It takes gigantic efforts to build a stable and flourishing economy after centuries of servitude that these nations have faced in the name of colonization. The writers undertaken for this study not only address native issues, but also focus on the idea of deconstructing the Euro-American literary hegemony. They focus on unbiased expression and try to create a platform for the budding writers to flourish. The 
power of literature exceeds all other powers and has the potential of bridging the gap between people across the globe.

The female authors from Pakistan have been vehemently expressing their concerns. They are boldly speaking against the dictates of patriarchy in their society, biased codes of social conduct, religious hypocrisy, sexual abuse, crumbling economy and negative impact of colonization. Tehmina Durrani in her famous novel Blasphemy (1998) narrates the true story of a woman who suffered due to poverty, patriarchy, distorted religious dictates and inequality. Her life is ruined by the institution of marriage and she is perpetually abused by her husband who treats her like a commodity. Ultimately she feigns death to escape further atrocities at the hands of her son, who too is a patriarch like his father. During the course of the novel, Durrani plunges from past into present. She tells the readers how difficult it gets for a woman to survive in a set up where religion is used as a tool to suppress her and deprive her of her dignity. She is forced into prostitution by her husband and is made to satiate the lust of her husband by providing him helpless, young and poor women in order to protect her own daughter. The atrocities she endures are heartbreaking and shocking. The gruesome realities exhibited by Durrani establish her as an ace feminist writer. Durrani was immensely motivated by Edhi's spirit of kindness and goodwill. In the year 1994 she penned his autobiography entitled A Mirror to the Blind. Durrani in her autobiography entitled My Feudal Lord (1991), and her debut novel Blasphemy (1998) talks of female subjugation under the banner of patriarchy and orthodoxy. These novels exhibit the dreadful realities of women living under dictatorial religious regimes.

Another prolific author from Pakistan known as Faiqa Mansab candidly narrates the sad tale of women in the city of Lahore. In her debut novel This House of Clay and Water (2017) she verbalizes a tale of forbidden love between a hermaphrodite and a married woman. She also focuses on the plight of the transgenders and underprivileged people in her novel. 
Monotonous marital bonds, inflated male egos, prostitution, incest and sexual abuse are dealt with artistic sensibility in this text. The story ends on a tragic note with the death of the transgender protagonist. The love that blossoms between the female protagonist and the transgender resulted in his death. Though the love between them was pious, yet he paid its heavy price because he dared to go against the conventions of the society. The transgenders are physically exploited and insulted on account of their gender. They are denied opportunities and pushed to the margins of the society. Mansab's deep insight into their plight brings to light a long neglected concern.

Traversing across borders this scholarly effort drifts towards the writings of an illustrious Egyptian author Nawal El Saadawi. As a female physician, psychiatrist and social activist her literary corpus is not only massive, but thoroughly impressive. The psychoanalytical quality of her fiction is enigmatic. Her fictional works exhibit profound knowledge of the women of Egypt and their concerns. As a writer Saadawi has aesthetically united art and medicine in her works by delving into the psyche of her characters so as to understand and extract the most subtle nuances of human mind and personality. She arouses our sympathy towards the marginalized prisoners who are condemned by laws and sent to the fringe of the society to suffer and perish in anonymity. Every sinner has a story to narrate and all sinners are not actually depraved people and they must be given an opportunity to speak. The dialogic nature of her novels makes them all the more fascinating. In her famous novel Woman at Point Zero that was written in Arabic in 1975 and translated to English in 1983, she narrates the story of a woman prisoner named Firdaus a night before her execution. The prisoner speaks after years of silence to a female psychiatrist who pens down her tale truthfully. The story of the female prisoner is full of sexual abuse beginning from incest and finally leading to whoredom. Women are consumed by men as a commodity and are cheaply priced. The female prisoner speaks against the men who exploited her. She was charged and 
imprisoned on account of the murder of her pimp. She finally asserted control of her life by confessing her crime and speaking the truth about social evils that tormented her. She retained her dignity by refusing to be pardoned for her crime because she believed that the pimp she murdered deserved to die that way. He reduced women to utter poverty by snatching their earnings and by exploiting them mercilessly. In death she was finally raised from an ordinary to an ethereal life that was extraordinary and independent. Some other distinguished works of Saadawi that have been translated from Arabic to English include Women and Sex (1972), The Circling Song (1978), The Fall of the Imam (1987), The Innocence of the Devil (1994), Love in the Kingdom of Oil (2000), Zeina (2011). Her writings in Arabic include a vast collection of non-fictional works, memoirs and plays.

British-Bangladeshi author Tahmima Anam has also achieved International repute for her literary efforts. Some of her notable works include A Golden Age (2007), The Good Muslim (2011) and The Bones of Grace (2016). Her short stories and columns are also wellknown. Being a British-Bangladeshi, she is deeply aware of the abyss between the GN and the GS. Her roots in Bangladesh do not restrict, or deter her from writing about her views regarding her native land. In her debut novel A Golden Age she describes the Bangladeshi war of independence. In this historical novel she deals with the themes of motherhood and the predicaments that surround it, the idea of nationalism is dealt with skill and the way women are affected by wars. The catastrophe that overwhelmed the people in search of freedom had great impact on the future generations after the war ended. The journey from East Pakistan to Bangladesh was not an easy one as shown by Anam. The advent of war changed many lives. The themes of migration, refugees, cruelty and quest for freedom make this novel fascinating. Another famous writer who carries a small portion of the global south in her heart is Monica Ali. Though she has a British nationality, yet the memories of her country are present in writings. Her famous books include Brick Lane (2003), Alentejo Blue (2006), In the 
Kitchen (2009) and Untold Story (2011). The novel shortlisted for Man Booker prize called Brick Lane won her great prominence. It tells the story of a young Bangladeshi girl called Nazneen who migrates to London to marry an elderly man. They make an average couple, and the novel narrates her adaptation to the new life in London and the other features related to their ethnic community in London. The title of the novel Brick Lane has been inspired by an actual street with similar name in London that houses London's Bangladeshi community. Another author who is a British national with Bangladeshi roots is Zia Haider Rahman. His debut novel In the Light of What We Know (2014) earned him international acclaim. He won the James Tait Black Memorial Prize for this novel. The novel was greatly appreciated by the critics. His first novel is an adventurous novel that cannot be strictly outlined because of its wide action. It is an intensely deep novel with focus on psychological aspects as well as geographical references. It has all the elements that make it a successful contemporary narrative.

Arundhati Roy is a notable female Indian author who has won Man Booker Prize in 1997. She won the prize for her debut novel God of Small Things (1997). After years of research she penned her second novel entitled The Ministry of Utmost Happiness (2017). She is a socio-political activist, novelist, a feminist and an environmentalist. She has won the Sydney Peace Prize in 2004 and Norman Mailer Prize in 2011. Her corpus of non-fictional works include The End of Imagination (1998), The Greater Common Good (1999), The Algebra of Infinite Justice (2002), Walking with the Comrades (2011), Kashmir: The Case for Freedom (2011), The Doctor and the Saint (2017) and a collection of her nonfictional works published under the title My Seditious Heart (2019). In her recent novel The Ministry of Utmost Happiness she creates a narrative that is epic-like in grandeur. This novel relates the history of modern India that is ruthless, communal and severely unjust to several sections of the society. She diligently explores the issues of degenerating environment, poverty, 
unemployment, political insensitivity towards communal riots and massive killings, the helpless condition of the working populations who migrate to cities in search of work and better resources, the vast construction of dams by ruining the rivers, adulterated food production and Kashmir insurgency. She weaves these themes in the fabric of her narrative outlining the story of a transgender called Anjum and her community in old Delhi. The novel conveys the message of the author who upholds the idea of freedom and equality with great sincerity. The appeal is colossal and the cerebral concerns of the novel are equally profound. Roy is a writer who brings to surface the idea of equality, freedom and justice for all humans. Her revolutionary stand creates a platform for discourse between the oppressor and the oppressed. In a lecture delivered at Seymour Theatre Centre in Sydney, Roy candidly stated that, "There's really no such thing as the voiceless. There are only the deliberately silenced, or the preferably unheard" (n. pag.).

Latin American author Mario Vargas Llosa is a Peruvian writer, politician, essayist and journalist. He is a major writer of the Latin American Boom. He has won the Nobel Prize for Literature in 2010. Some of his famous works include The Time of the Hero, The Green House, Conversations in the Cathedral, Aunt Julia and the Script Writer, The Neighborhood (2018). His fiction surpasses literary genres from historical works, to murder mysteries, comedies and thrillers. Similarly Giannina Braschi is a Puerto Rican author who is famous for her trilogy of postmodern poetry, Empire of Dreams (1994). She has also won fame for her philosophical fiction entitled United States of Banana (2011) and her first Spanglish novel called Yo-Yo Boing! (1998). She writes upon varied themes and subjects including freedom, immigration, capitalism, censorship and democracy. She is a versatile author who writes across genres.

Junot Díaz is a Dominican-American author who is particularly appreciated for his canonical works including a short story collection Drown (1996) and his novel The Brief 
Wondrous Life of Oscar Wao (2007). He also won the Pulitzer Prize for Fiction in 2008 for this novel. Prominent authors have also emerged from Nigeria; Nnedi Okorator is one such author. She is a Nigerian-American author who writes novels for children and adults. She has written numerous works of fiction including The Shadow Speaker, Zahrah the Windseeker, Who Fears Death, Lagoon and Binti Trilogy. Tanure Ojaide is a Nigerian poet and a famous writer. He won the Wole Soyinka Prize for Literature in Africa in 2018 for his collection entitled Songs of Myself: A Quartet (2015). His notable fictional works include Sovereign Body (2004), The Activist (2006), Matters of the Moment (2009), Stars of the Long Night (2012) and God's Naked Children (2018). Some of his poetic works include; The Endless Song (1988), The Blood of Peace (1991), In the House of Words (2005), Love Gifts (2013), Songs of Myself (2015) and The Questioner (2018). Like Tanure, Ben okri is another celebrated Nigerian poet, playwright and novelist. Okri is universally acclaimed as a postmodern and postcolonial author. He won the Booker Prize for Fiction in 1991 for his novel The Famished Road. His use of the element of fantasy, coupled with magic realism adds to his expertise. Oral tradition is employed in his works and the civil war in Nigeria had great impact on his writings. Some of his notable novels include The Famished Road (1991), Dangerous Love (1996), Infinite Riches (1998), Star book (2007) and The Age of Magic (2014). Some of his poetic collections include; An African Elegy (1992), Mental Fight (1999), Wild (2012) and Rise like Lions (2018). His writings are motivating and full of optimism. He states in The Famished Road, "We can change the world" (n.pag.).

Some legendary writers from across the globe have given a renewed identity to the literary traditions of their respective countries. These writers have added to the canon of literary production from the GS. The writers have given a new face to the Diaspora studies and the translation studies on an international platform. The writers who have ardently contributed to the corpus of literature from the GS include Salman Rushdie, Anita Desai, 
Chimamanda Ngozi Adichie, Ru Freeman, Khaled Hosseini, Pamela Allen and Eka

Kurniawan. The difference between the GN and the GS can only be eliminated if there is unbiased approach to solve this issue. The global injustice that is manifested in form of this division must be completely rooted out to allow the world to be a safe place for every human being. The writers briefly studied in this paper make relentless efforts to inculcate a sense of pride in the people to celebrate their cultural legacy. They pave way for future discourse that can scale new heights of critical excellence. These writers from various nations of the Global South deconstruct the established literary codes, invent their own narrative patterns, create discourse that is independent and cosmopolitan in appeal, they have a wide spectrum of themes focusing on the immediate reality of the people and they engage in modes of expression that are often inspired by their native culture. The GS has learnt to retort to the unjust ideologies of the GN in a constructive way.

It can be aptly concluded that the writers of the GS have created an international rostrum for their literary efforts. Their literary corpus has earned global readership and acclaim, and has made the GN aware of the infinite possibilities that GS has in various spheres. The writings from GS have challenged the writings of the GN with their skilled and intense portrayal of life. The literature of the global south adheres to the international climate, it addresses postmodern debate, and it is philosophical and deeply interwoven with native cultural values and nuances. It tries to bring the margins towards the mainstream for the purpose of collective welfare and national progress. There is philosophical depth, artistic creativity and semantic excellence in the literature that emerges from the Global South. 


\section{Works Cited}

Saadawi, Nawal El. A Daughter of Isis: The Early Life of Nawal El Saadawi. 1999.Trans.

Sherif Hatata. New York: Zed Books, 2009. Print.

Okri, Ben. The Famished Road. 1991. London: Vintage, 2003. Print. 